\title{
Edukasi Masyarakat dalam Meningkatkan Ketahanan Pangan Keluarga di Masa Pandemi COVID 19
}

\author{
Safriadi ${ }^{1^{*}}$, Rahmatulah ${ }^{1}$, Ashar ${ }^{1}$ \\ ${ }^{1}$ Universitas Hasanuddin, Jl. Perintis Kemerdekaan KM.10 Tamalanrea, Makassar, Sulawesi Selatan \\ *Email koresponden: safrimku@gmail.com
}

\author{
ARTICLE INFO \\ Article history \\ Received: 31 Ags 2020 \\ Accepted: 04 Des 2010 \\ Published: 23 Apr 2021
}

\section{Kata kunci:}

Covid 19

Edukasi

Ketahanan Pangan

\begin{abstract}
A B S T R A K
Background: Salah satu permasalahan yang terjadi pada masa pendemik covid 19 adalah melemahnya ketahanan pangan pangan masyarakat sebagai akibat dari kebijakan untuk mengurangi aktivitas bekerja di luar rumah yang befrtujuan untuk mencegah penyebaran virus tersebut. Akibat dari berkurangnya aktivitas tersebut, masyarakat yang sumber penghasilannya berkurang khususnya mereka yang bekerja selama ini harus diluar rumah. Metode: Demikian yang dengan sendirinya berdampak pada pendapatan keluarga. Disisi lain kebutuhan pangan keluarga tidak berubah bahkan cenderung bertambah mengikut frekuensi tinggal dirumah sangat tinggi. Untuk itu diperlukan upaya dalam rangka pemenuhan kebutuhan sehari-hari masyarakat yang dapat dilakukan tampak beraktivitas diluar rumah. Permasalahan yang terjadi kemudian adalah masih kurangnya pengetahuan masyarakat tentang bagaimana pemenuhan kebutuhan pangan terutama sayuran dapat dilakukan dengan memanfaatkan lahan sekitar rumah. Hasil: Solusi yang ditawarkan adalah meningkatkan pengetahuan mereka dengan kegiatan edukasi berupa pembuatan video tentang pemanfaatan ruang sempit untuk bercocok tanam dan tata cara bercocok tanam sayuran yang efektif dalam rangka pemenuhan kebutuhan pangan keluarga. Kesimpulan: Video tersebut kemudian disebarkan di media dan diharapkan akan ditonton oleh masyarakat dan mengaplikasikannya rumah masing-masing.
\end{abstract}

\section{A B S T R A C T}

Background: One of the problems that occurred during the Covid 19 outbreak was the weakening of the community's food security due to reduced maximum obligations to carry out activities outside the home to prevent the spread of the virus. As a result of the reduced activity, people whose sources of income are reduced, especially those who work so far, have to stay outside their homes. Methods: That in itself has an impact on family income. On the other hand, family food needs do not change and even tend to increase following the high frequency of staying at home. For that we need efforts to fulfill the daily needs of the community which can be done by doing activities outside the home. The problem that occurs then is the lack of public knowledge about how to fulfill food needs, especially vegetables, can be done by utilizing the land around the house. Results: The solution offered is to increase knowledge with educational activities in the form of making videos about the use of narrow land for farming and procedures for growing vegetables that are effective in meeting family food needs. Conclusions: The video is then distributed in the media and is expected to be watched by the wider community and applied in their respective homes

(C) 2021 by authors. Lisensi Jurnal Solma, UHAMKA, Jakarta. Artikel ini bersifat open access yang didistribusikan di bawah syarat dan ketentuan Creative Commons Attribution (CC-BY) license.

\section{PENDAHULUAN}

Mewabahnya Corona Virus Diseases-19 atau dikenal dengan Covid-19 yang menyebabkan bencana bagi masyarakat hingga mengakibatkan kematian ribuan jiwa diseluruh dunia, tidak terkecuali di Indonesia. Virus ini pertama kali muncul di Kota Wuhan, salah satu kota di Republik Rakyat Tiongkok dan menyebar ke seluruh penjuru dunia, tak terkecuali Indonesia. Pemerintah 
Indonesia mengonfirmasi kasus pertama Covid-19 yaitu pada tanggal 2 Maret 2020. Penyebaran Covid-19 yang sangat cepat, menyebabkan pemerintah Indonesia meresponnya dengan mengambil tindakan berupa menerapkan sistem Pembatasan Sosial Berskala Besar.

Penjabaran dari PSBB berupa langkah-langkah yang mengharuskan sistem social distancing dengan harapan agar dapat mengurangi bahkan memutus mata rantai infeksi Covid-19, sehingga seseorang diharuskan menjaga jarak antara setiap manusia dengan manusia lainnya dengan perhitungan jarak antar 1,5 hingga 2 meter dan tidak melakukan kontak langsung dengan orang lain tanpa menggunakan alat pelindung minimal. Selain itu juga diwajibkan melaksankan protokol kesehatan seperti mencuci tangan dengan air bersih yang mengalir, menggunakan setiap saat, menjaga jarak, menghindari kerumunan dan tetap berusaha selalu berada di rumah. Fenomena ini menggambarkan bahwa pandemi Covid-19 juga menyebabkan banyak perubahan dalam kehidupan sehari-hari, salah satunya pola makan. Pola makan masyarakat yang sehat selama pandemi perlu dijaga agar dapat meningkatkan sistem kekebalan tubuh, sehingga dapat mencegah infeksi Covid-19.

Saat munculnya wabah penyakit ini mendorong pentingnya untuk memberikan edukasi terhadap masyarakat tentang perilaku hidup bersih dan sehat dan juga tak lain adalah edukasi promosi penyuluhan mengenai sistem pertahanan imunitas atau kekebalan tubuh. Selain itu, masyarakat perlu mengetahui dengan pasti penularan dan cara pencegahan Covid-19 agar tidak terus mewabah. Masyarakat sangat disarankan untuk tinggal di rumah saja, harus menggunakan masker, pekerja/karyawan bekerja dari rumah (Work From Home/WFH).

Salah satu yang diharapkan dikumsumsi dalam masa pandemic adalah bahan pangan yang mengandung bahan untuk meningkatkatkan imunitas tubuh, seperti jahe, kunyit, buahbuahan dan sayur-sayuran. Selain itu banyak lagi bahan pangan lainnya yang dapat dikonsumsi dan cukup tersedia di lingkungan sekitar masyarakat sehingga sehingga keanekaragamaan jenis bahan makanan yang dapat dikonsumsi selama pandemi tanpa harus keluar jauh dari rumah. Salah satu bahan pangan yang mampu meningkatkan sistem kekebalan tubuh yaitu dari jenis umbi-umbian. Umbi-umbian sangat banyak ditemukan di sekitar masyarakat, berupa singkong, ubi jalar, kentang, gembili, talas, ganyong, garut, dan jenis umbi lainnya. Umbi-umbian juga mengandung karbohidrat yang sangat tinggi sebagai sumber energi sehingga dapat dijadikan bahan pengganti makanan pokok yaitu beras (Bantacut, 2010).

Mengacu pada konsep pangan yang termaktuk dalan Undang-Undang Nomor 7 tahun 1996 mengaskan bahwa pangan adalah segala sumber pangan yang berasal dari sumber hayati dan mengandung air, baik yang harus diolah maupun yang tidak diolah sebelum dikonsumsi manusia adalah termasuk dalam kategori bahan tambahan pangan, bahan baku pangan, dan bahan lain yang digunakan dalam proses penyiapan, pengolahan dan atau pembuatan makanan atau minuman untuk konsumsi sehari-hari(Purwaningsih, 2008).

Masalah berikutnya yang dapat terjadi adalah menurunnya imun akibat dari asupan gizi dari makanan yang tidak berimbang, sehingga sangat rentang untuk terpapar covid. karena acara kerja sistem imun yaitu membantu perbaikan DNA manusia; mencegah infeksi yang disebabkan oleh jamur, bakteri, virus, dan organisme lain; serta menghasilkan antibodi (sejenis protein yang disebut imunoglobulin) untuk memerangi serangan bakteri dan virus asing ke dalam tubuh. Tugas sistem imun adalah mencari dan merusak invader (penyerbu) yang membahayakan tubuh manusia (Fatmah, 2006).

\section{MASALAH}

Salah satu permasalahan yang dialami masyarakat adalah pemenuhan kebutuhan pangan terutama sayur-sayuran, mengingat bahwa sayuran sangat penting bagi tubuh. Buah dan sayur merupakan bahan pangan yang sangat memberi manfaat bagi tubuh (Wahyuni, 2020). Tarutama 
untuk mendukung kebutuhan akan vitamin. Vitamin merupakan kelompok senyawa organik yang tidak termasuk dalam golongan protein, karbohidrat maupun lemak, namun sangat penting bagi tubuh, terutama dalam meningkatkan imun (Hamidah, 2015). Masalah yang dihadapi dalam saat di era pandemik, kebutuhan akan sayur mayur tersendat karena pademik yang membuat orang jarang berinteraksi apalagi jual beli dan lebih banyak berada di rumah melakukan social distancing. Hal ini banyak mempengaruhi kedaulatan pangan rumah tangga. Terutama mereka yang masuk dalam kategori keluarga kurang mampu (Mulyo et al., 2016).

Untuk itulah kemudian dipandang penting memberikan solusi bagi penyelesaian masalah tersebut dengan cara mengedukasi masyarakat dengan video dan kebun pencontohan hidroponik dalam pemenuhan kebutuhan pangan berupa sayuran yang aman dilakukan di masa pendemik ini yang dilaksanakan di Perumahan Gelora Baddoka Indah, Kelurahan Pai, Kecamatan Biring Kanaya, Kota Makassar, Sulawesi Selatan..

\section{METODE PELAKSANAAN}

Metode pelaksanaan kegiatan yang dilakukan adalah video simulasi kegiatan budidaya sayuran dengan teknik hidroponik yang kemudian diupload dimedia sosial dan untuk lingkungan sekitar dibuat berupa kebun percontohan untuk menjadi pilot project bagi masyarakat sekitar kompleks perumahan. Penggunaan media social sebagai metode dalam kajian antropologi virtual sangat mumudahkan dan bermanfaat terutama jika terkait dengan kondisi yang tidak terjangkau secara fisik (Achmad \& Ida, 2018)

Setelah dilakukan intervensi, selanjutnya dilakukan evaluasi intervensi. Evaluasi dilakukan dengan melihat respon masyarakat terhadap video yang disebar yang berupa jumlah orang yang menontong, dan yang memberikan like pada video tersebut. Sedangkan untuk evaluasi terhadap kebun percontohan disekitar rumah dievaluasi berdasarkan pada ketertarikan, minat dan yang mencoba untuk membuat kebun sendiri. Waktu evaluasi dilaksana pada minggu pertama setelah upload video dan selanjutnya dilaksanakan setelah 1 bulan pertama hingga tiga bulan.

Berikut tahapan pelaksanaan kegiatan pengabdian masyarakat yang dilaksanakan dalam edukasi masyarakat dalam pemenuhan kebutuhan pangan keluarga dalam masa pendemi covid 19 di Kota Makassar sebagai berikut :

1. Tahapan penyiapan bahan-bahan untuk membuat wadah tanaman sayur hidroponik. Bahan bahan yang disiapkan antara lain bibit tanaman, wadah pembibitan dan wadah pemeliharaan.

2. Tahapan berikutnya proses pembuatan wadah dan penyemaian bibit pada wadah yang telah disiapkan.

3. Penanam benih pada wadah botol plastic bekas untuk pemeliharaan tanaman.

4. Semua tahapan di atas direkam dalam bentuk video rekaman dismartphone

5. Editing sederhana terhadap video tersebut, dan selanjutnya diupload di youtube (https://www.youtube.com/watch? $\mathrm{v}=\mathrm{hnBdI} 3 \mathrm{hWpFc}$ ) dan linknya kemudian di share ke WhasApp dan Facebook.

\section{HASIL DAN PEMBAHASAN}

Konsep "ketahanan pangan" pertama kali diperkenalkan penggunaannya secara ilmiah pada pertengahan 1970-an yakni pada konferensi dunia tentang makanan. Dalam konfrensi tersebut dibicarakan kebutuhan pangan secara global dihubungkan dengan tingkat kebutuhan berdasarkan pertumbuhan penduduk dunia yang dikaitkan dengan produksi dan harga secara keseluruhan. Kesimpulan dari konfrensi tersebut tentang pengertian ketahan pangan bahwa ketahanan pangan mengacu pada kondisi ketika semua orang selalu memiliki akses fisik dan ekonomi yang aman dan bergizi dengan jumlah yang cukup untuk memenuhi kebutuhan dan 
minat mereka pada makanan yang dibutuhkan untuk hidup aktif dan sehat. Konsep ini Ini sekali lagi menegaskan upaya dalam mewujudkan cita-cita masyarakat dunia untuk mencapai "kebebasan dari kemiskinan", yang diharapkan menjadi kebijakan yang bersifat nasional (Kuzmin, 2016).

Sedangkan konsep lain yang senada oleh Bulog bahwa ketahan pangan adalah hak negara menentukan kebijakan Pangan secara mandiri dengan memberikan jaminan atas hak kebutuhan makanan bagi penduduk dan memberikan hak bagi masyarakat dalam menentukan sistem pangan yang tepat dengan mengacu pada potensi sumber daya lokal.

Pendemi sebagai salah satu penyebab dari munculnya ketidakberdayaan masyarakat karena terbatasnya akses ekonomi, yang kemudian berdampak pada sektor ketahanan pangan masyarakat. Maka perlu upaya perberdayaan dalam rangka meningkatkan kapasitas diri dan masyarakat untuk survive bahkan revive terhadap ancaman pandemic covid 19. Pemberdayaan masyarakat dalam hal ini dipahami sebagai meningkatkan kapasitas masyarakat sehingga mampu bertindak dan berkreasi untuk pemenuhan kebutuhannya (Irawan et al., 2020).

Dalam kegiatan pengabdian yang dilakukan tahapan-tahapan edukasi sebagai bagian dari kegiatan pemberdayaan dalam rangkan meningkatkan kapasitas kognisi masyarakat untuk adaptif dimasa pendemik covid 19. Kegiatan yang dilakukan dalam rangka mendukung ketahanan pangan keluarga berupa video edukasi dan kebun hidroponik percontohan dengan harapan sedapat mungkin dapat berkonstribusi dalam meningkatkan kapasitas pengetahuan untuk diwujudkan dalam bentuk tindakan rasional. Dalam kajian sosiologi dijelaskan bahwa bahwa salah penentu dari tindakan manusia adalah sistem pengetahuan yang dimiliki sebagai bahan dasar dalam mempertimbangkan sebuah tindakan (Muhlis \& Norkholis, 2016). Demikian juga dalam perspektif ilmu komunikasi dijelaskan bahwa respon akan menentukan stimulus. Teori Stimulus-Respond mengemukakan bahwa pesan-pesan media yang berisi stimulus yang menghasilkan respon yang berbeda-beda dari kalangan khalayak. Efek yang ditimbulkan adalah reaksi khusus terhadap stimuli sehingga akhrinya seseorang dapat mengharapkan dan memperkirakan kesesuaian antara pesan dan reaksi komunikan (Kurniawan, 2018). Jadi video dan kebun percontohan adalah stimulus yang berikan dan tindakan mencontoh atau men-like video adalah respon dari masyarakat. Hal inilah kemudian yang dijadikan indikator tercapainya target dalam kegiatan edukasi dalam rangka mendukung ketahanan pangan keluarga di masa pandemic covid 19.

Pemilihan model video dengan pertimbangan bahwa memudahkan dalam menyebarkan dimedia sosial yang saat pandemic seperti ini cukup efektif untuk menjangkau nitizen karena saat orang lebih banyak dirumah. Meskipun ada hambatan-hambatan berupa tidak terfokus sasaran edukasi pada wilayah maupun segment tertentu. Demikian juga dengan kebun percontohan masih terbatas pada tetangga sekitar rumah sehingga proses peningkatan kapasitas masyarakat dalam meningkatkan ketahanan pangan keluarga masih menemui kendala.

Rangkaian kegiatan pengabdian meliputi persiapan pengabdian dilakukan dengan penyiapan wadah untuk tempat persemaian bibit. Bibit ini dapat diperoleh dengan cukup mudah ditoko-toko pertanian. Meskipun kemudian terkendala dengan kurang toko yang buka. Namun demikian bibit tanaman dapat kami peroleh di Fakultas Pertanian Universitas Hasanuddin, sehingga kendala tersebut dapat di atasi.

Kegiatan ini dibuat dalam bentuk video rekaman dengan narasi yang mendeskripsikan perjalanan pelaku pengabdi masyarakat dalam melaksanakan kegiatan di awali dari proses mendapatkan bibit, penyiapan wadah, proses pembuatan hidroponik, hingga sampai pada upload di media sosial. Meskipun dalam pembuatan video hanya menggunakan alat sederhana yaitu rekaman video dari smartphone, namun video hasil rekaman cukup jernih dan jelas. Selanjutnya 
proses editing videonya juga menggunakan aplikasi sederhana hingga jadilah sebuah video sosialisasi yang diupload di youtube

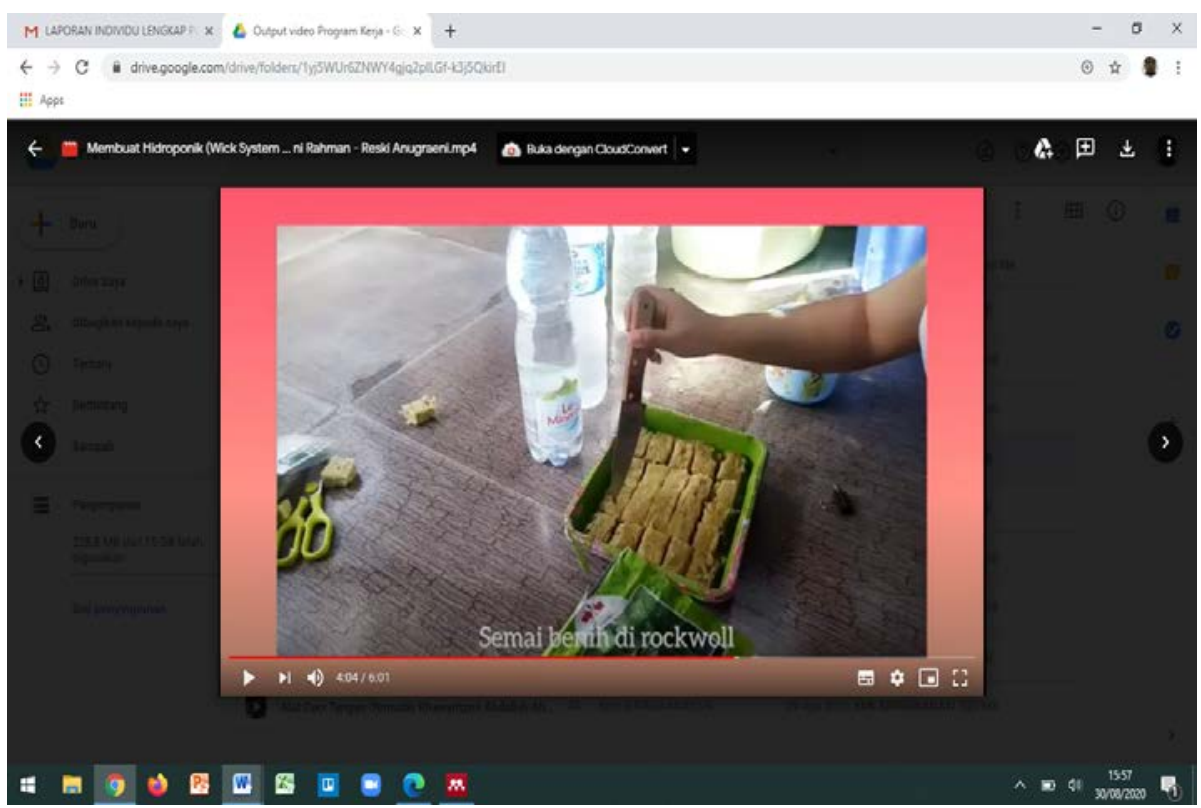

Gambar 1. Bibit Tanaman Siap Disemaikan di Rockwall

Berikutnya adalah mencari wadah untuk persemaian dan penanaman bibit. Wadah unutk persemaian bibit digunakan rockwall atau biasa disebut sebagai media tanam hidroponik (Benton Jones, 1985; Kornberg, 2012). Rockwool terbuat dari batuan basah yang dipanaskan hingga meleleh. Sebagai suatu media tanaman hidroponik, rockwool merupakan wadah pengganti fungsi tanah, untuk rumah bagi akar dari tanaman (Slamet, 2020). Sedangkan wadah untuk penaman yang dipilih adalah botol plastic bekas yang banyak terbuang ditempat sampah. Botol ini dipilih ukuran besar 1,5 liter yang kemudian dipotong bagian atasnya. Selanjutnya dicuci bersih dan kemudian diisi dengan kompos. Penggunaan kompos untuk menjadi tempat tumbuhnya bibit sayuran karena pertimbangan bahwa wadah plastic dan komposnya dapat menyimpan air sehingga lebih memudahkan untuk pemenuhan kebutuhan air dari tanaman (Putra \& Yuliando, 2015).

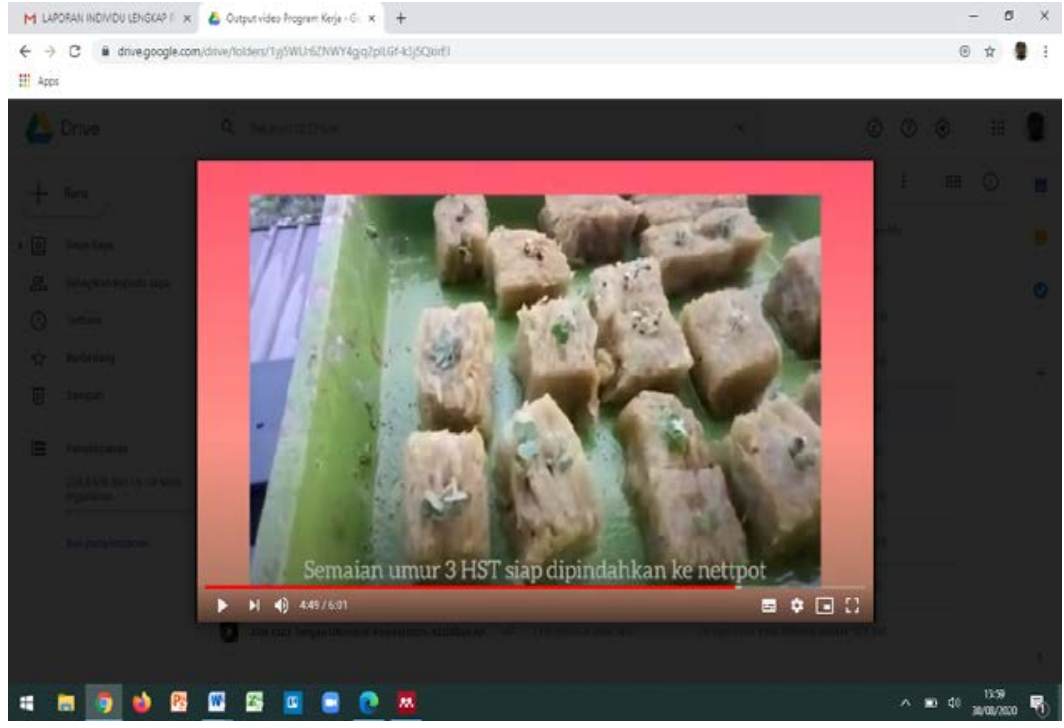

Gambar 2. Bibit Tanaman yang telah Tumbuh 
Bibit ini yang telah tumbuh berumur sekiar 4-6 hari segera disiapkan untuk dipindahkan ke neetpot. Netpot adalah wadah media tanam untuk bertanam Hidroponik. Seperti pot kecil dengan lobang di bawahnya dan dibagian samping, sehingga ketika akar tanaman keluar dari netpot mudah untuk dicabut. Dengan ukuran yang variatif, ukuran yang umum digunakan adalah tinggi dan diameternya $5 \mathrm{~cm}$ namun itu juga tergantung kepada pemilik tanaman. Neetpot itu adalah wadah untuk pemeliharaan tanaman yang diambil dari botol. Pertimbangan untuk memilih botol bekas sebagai nettpot adalah bagian dari mengurangi sampah plastic yang banyak merusak lingkungan (Purwaningrum, 2016).

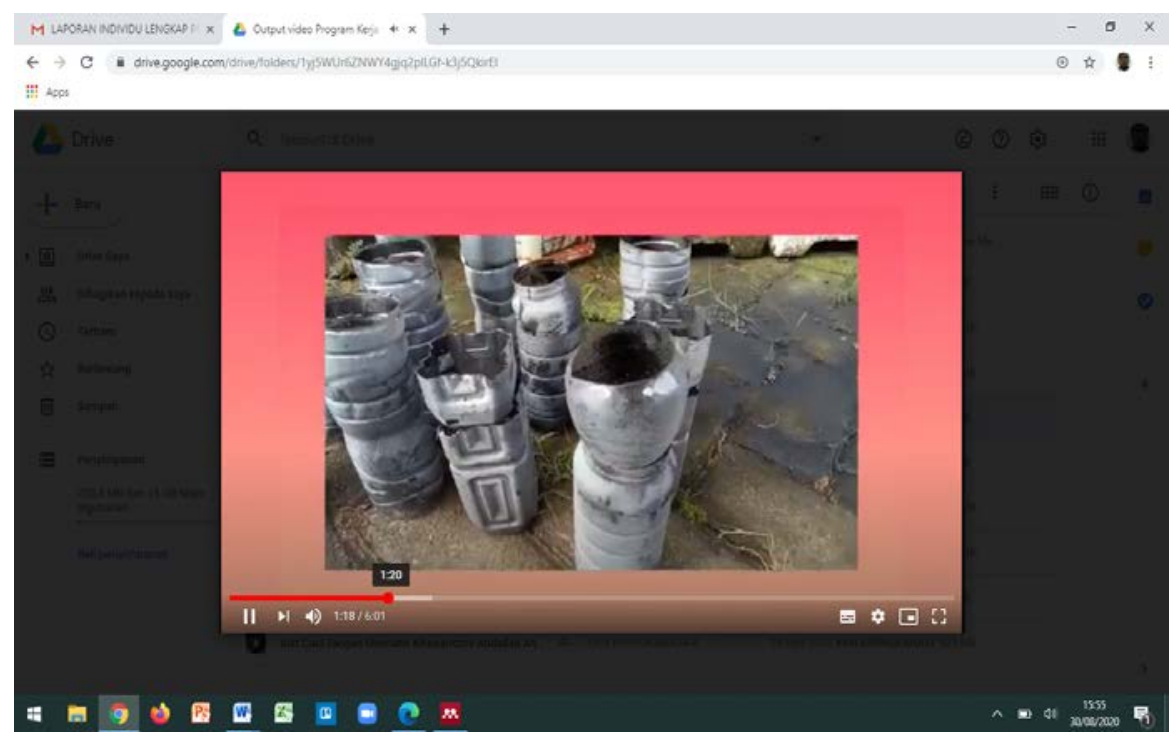

Gambar 3. Wadah Plastik Untuk Tanam Sayuran

Dari rangkaian kegiatan ini ada beberapa hal yang dapat dipetik sebagai keunggulan dari progman pengabdian masyarakat berbasis media, antara lain bahwa kegiatan tetap bisa dijalan meskipun berlaku PSBB. Sehingga tetap dalam koridor sesuai dengan aturan yang ditetapkan Kemenkes terkait PSBB di Kota Makassar. Demkian juga dengan kebun pencontohan juga dapat dilaksanakan sesuai dengan protok kesehatan. Meskipun demikian semua dapat terlaksana dengan baik namun tetap belum bisa mencapai target terutama masyarakat nitizen yang merupakan penerima manfaat tidak bisa dikontrol karena hanya dishare ke media sosial yang merupakan belantara tersendiri dan bebas. Akses untuk mengetahui hanyalah sebatas data statistik yang ditampilkan dari dari berapa kali orang mengakses video yang ditampilkan. Namun demikian dalam seiring berjalannya waktu disertai dengan sosialisasi dalam bentuk share link serta share nomor kontak untuk wadah menerima pertanyaan terkait video tersebut diharapkan video tersebut dapat memberi manfaat dan solusi terhadap pemenuhan satu kebutuhan pangan rumah tangga berupa sayuran.

\section{KESIMPULAN}

Kegiatan pengabdian terlaksana sesuai dengan target perencanaan dimana out put berupa video rangkaian pembuatan media tanaman hidroponik dan kebun percontohan terlaksana dengan lancar. Selanjutnya upload di youtube dan dibagi media sosial Facebook dan Instagram juga berhasil dilakukan. Hanya saja target pencapaian berupa like youtube belum mencapai target yaitu 50 orang like di minggu pertama upload. Untuk itu evaluasi di dilakukan dalam satu bulan pertama dengan mengupayakan promosi dengan share link ke berbabagi group WhatsApp, Facebook serta media sosial lainnya. Demikian juga dengan kebun percontohan di lingkungan 
perumahan juga belum tercapai yakni hanya dua keluarga dari 5 keluarga yang direncanakan membuat dalam 2 minggu kegiatan kebun di mulai. Untuk itu disarankan kepada para pembaca men-like $\neg$ video simulasi pembuatan kebun hydroponic tersebut dan dijadikan referensi untuk kegiatan dalam rangka hidup di era penormalan baru.

\section{UCAPAN TERIMA KASIH}

Sebagai penutup dari tulisan ini penulis ucapkan terima kasih kepada Rektor Universitas Hasanuddin dan khususnya kepada lembaga penelitian dan pengabdian masyarakat universitas hasanuddin yang telah membiayai sepenuhnya kegiatan pengabdian masyarakat ini. Tak lupa pula ucapan terima kasih kepada P2KKN yang telah menfasilitasi penulis untuk melaksanakan pengabdian bersamaan dengan kegiatan KKN Tematik mahasiswa universitas hasanuddin.

\section{DAFTAR PUSTAKA}

Achmad, Z. A., \& Ida, R. (2018). Etnografi Virtual Sebagai Teknik Pengumpulan Data Dan Metode Penelitian. The Journal of Society \& Media, 2(2), 130. https://doi.org/10.26740/jsm.v2n2.p130-145

Bantacut, T. (2010). Ketahanan Pangan Berbasis Cassava. Jurnal Pangan, 19(1), 3-13.

Benton Jones, J. (1985). Growing Plants Hydroponically. In American Biology Teacher (Vol. 47, Issue 6). https://doi.org/10.2307/4448083

Fatmah. (2006). Respons Imunitas yang Rendah pada Tubuh Manusia Usia Lanjut. Makara Kesehatan, 10(1), 47-53.

Hamidah, S. (2015). Sayuran dan Buah Serta Manfaatnya Bagi Kesehatan Disampaikan dalam Pengajian Jamaah Langar Mafaza Kotagede Yogyakarta. Fakultas Teknik Universitas Negeri Yogyakarta, 1-10.

Irawan, P. L. T., Kestrilia Rega Prilianti, \& Melany. (2020). Pemberdayaan Usaha Kecil Menengah (UKM) Melalui Implementasi E-Commerce di Kelurahan Tlogomas. Jurnal SOLMA, 9(1), 33-44. https://doi.org/10.29405/solma.v9i1.4347

Kornberg, S. (2012). Hydroponic System. Hydroponic System by Computer, 36.

Kurniawan, Y. I. (2018). Pembangunan Website Informasi Sekolah Di Sma Negeri Kerjo, Karanganyar. Jurnal Pengabdian Kepada Masyarakat (J-ABDIPAMAS), 2(1), 71-84.

Kuzmin, E. A. (2016). Sustainable food security: Floating balance of markets. International Journal of Economics and Financial Issues, 6(1), 37-44.

Muhlis, A., \& Norkholis, N. (2016). ANALISIS TINDAKAN SOSIAL MAX WEBER DALAM TRADISI PEMBACAAN KITAB MUKHTASHAR AL-BUKHARI (Studi Living Hadis). Jurnal Living Hadis, 1(2), 242. https://doi.org/10.14421/livinghadis.2016.1121

Mulyo, J. H., Sugiyarto, S., \& Widada, A. W. (2016). Ketahanan Dan Kemandirian Pangan Rumah Tangga Tani Daerah Marginal Di Kabupaten Bojonegoro. Agro Ekonomi, 26(2), 121. https://doi.org/10.22146/agroekonomi.17265

Purwaningrum, P. (2016). Upaya Mengurangi Timbulan Sampah Plastik Di Lingkungan. Indonesian Journal of Urban and Environmental Technology, 8(2), 141. https://doi.org/10.25105/urbanenvirotech.v8i2.1421

Purwaningsih, Y. (2008). Ketahanan Pangan: Situasi, Permasalahan, Kebijakan, Dan Pemberdayaan Masyarakat. Jurnal Ekonomi Pembangunan: Kajian Masalah Ekonomi Dan Pembangunan, 9(1), 1. 
https://doi.org/10.23917/jep.v9i1.1028

Putra, P. A., \& Yuliando, H. (2015). Soilless Culture System to Support Water Use Efficiency and Product Quality: A Review. Agriculture and Agricultural Science Procedia, 3, 283-288. https://doi.org/10.1016/j.aaspro.2015.01.054

Slamet, et all. (2020). Peningkatan Keterampilan ICT untuk Guru melalui Pelatihan Konten Digital Berbasis Sumber Terbuka. Open Source, 4(2), 118-130.

Wahyuni, S. (2020). Sosialisasi Pemanfaatan Jambu Air Menjadi Nata De Syzigium. Dinamisia: Jurnal Pengabdian Kepada Masyarakat, 4(1), 209-213. https://doi.org/10.31849/dinamisia.v4i1.3285 